\title{
Making the Nigerian School Environment and Curriculum More Functional and Responsive for Human Capacity Development for the Year 2020
}

\author{
Comfort Ebere Mbachu ${ }^{1, *}$ \& Dorgu, Theresa Ebiere ${ }^{1}$ \\ ${ }^{1}$ Dept. of Teacher Education, Faculty of Education, Niger Delta University, Wilberforce Island, Bayelsa State, \\ Nigeria \\ *Corresponding author: Dept. of Teacher Education, Faculty of Education, Niger Delta University, Wilberforce \\ Island, Bayelsa State, Nigeria. E-mail: ebymbachu2007@yahoo.com
}

Received: November 6, 2013

Accepted: December 16, 2013

Online Published: January 6, 2014

doi:10.5430/jct.v3n1p28

URL: http://dx.doi.org/10.5430/jct.v3n1p28

\begin{abstract}
Education is seen as an instrument "per excellence" for effecting national development. Education is seen as a means of developing potentialities and capacity building. Any educational Curriculum that aims at developing human potentials must target at functionality. Functionality here refers to curriculum that is designed to teach students skills that will enable them function as competent and acceptable adults. Obviously, school environment is one of the most important factors that determine the success of a well designed curriculum. This study tries to give the concept of functional curriculum and school/ learning environment. It looks into the various ways the school curriculum can be made functional and responsive for human capacity development in Nigeria. The paper as well discuses what is expected of education/knowledge to pursue as we journey into the year 2020. The paper equally explains the challenges hindering the quick realization of functional curriculum that is expected to develop human capacity. The paper concludes and made recommendations on how to make the Nigerian school curriculum more functional for human capacity development.
\end{abstract}

Such recommendations includes:-

$\checkmark$ Provision of necessary school facilities and infrastructure.

$\checkmark$ Proper curriculum assessment and monitoring of what goes on in the education sector.

Keywords: school environment; responsive curriculum; functionality; human capacity development; practical skills; human productivity

\section{Introduction}

"Human development is about putting people at the centre of development. It is about people realizing their potentials, increasing their choices and enjoying the freedom to lead lives they value, human development is a development paradigm that is about much more than the rise and fall of national incomes. It is about creating an environment in which people can develop their full potentials and lead productive, creative lives in accord with their needs and interests. People are the real wealth of nations. Development is thus about expanding the choices people have to lead lives that they value. Without human beings in the inter- and intra-generational sense, there can be no sustainable Development” (Obanya 2009:3)

Obanya is of the opinion that what makes Education central to any discussion of sustainable development is that Education deals with the awakening and nurturing of human potentials. Education also deals with the conservation and of human heritage (environment, economic, social, and cultural). Throughout ages, and in all climes, Education involves the trans-generation of heritage. Since human being has to be educated to develop/maximize his capacity to function as the motor of sustainable development, his Education should be sustainable.

The ultimate aims of education here is to bring out the best in each individual for its benefit and that of the society. Education is an investment against poverty. This aim can only be achieved when the school curriculum is functional 
and responsive enough in developing human capacity.

In other to achieve functionality, the decade 1990 to 2000 has been correctly referred to as the "Decade of World Submit", because the world witnessed a plethora of international conferences mainly devoted to "Quality in Education" for human capacity development. Among such conferences is "World Conferences on Education for All" held in 1990 at Jomtien and another in Dakar, 2000. Several important messages came out of these conferences, among which are "an affirmation that education is a fundamental human right" and "an acknowledgement that Africa as a continent is at the bottom of the world's educational league table, and the fact that this should justify urgent concerted innovative responses. (Obanya in Ijaiya, 2004; 2)

\subsection{Concept of Functional Curriculum}

Curriculum is the heart of any Educational system.

- Functional curriculum is the curriculum designed to teach students skills which will allow them to function as competent and accepted adults. Functional curriculum for human capacity development is the type of curriculum which Offorma (2005) calls “Curriculum for Wealth Creation”. Curriculum for wealth creation can be regarded as entrepreneurial knowledge, skills and attitudes which is called "Occupational Survival Skills". Such skills relate to problem solving, human relations, decision making, and effective communication. Hodgett in Offorma (2005) identifies technical competence, mental ability, human relation skills and creativity as the required skills for human capacity development skills.

- Curriculum that is said to be functional is a curriculum that enables the learners to acquire the skills that can be used or enable the learner or student cope in the world of work. What matters in the $21^{\text {st }}$ century is no longer "what you know, but what you can do".

* A functional curriculum should be a curriculum for human development that prepares the student for career/vocation. Such should be;

- $\quad$ activity based curriculum

- $\quad$ it should be a curriculum for meeting ones interest and ability

- it should be a curriculum for gainful engagement.

- $\quad$ it should be a curriculum that will prepare the students to exhibit their skills.

\subsection{Concept of School/Learning Environment}

Learning or school environment as defined by Unachukwu (2010) could be seen as the place and setting where learning occurs. It includes social, Psychological and the Physical setting, the Interpersonal and Instructional characteristics which influence students performance. Nwabueze (2012) sees learning environment to include; general infrastructure, class size, quality of teachers, the teaching-learning process (quality of teaching); the level of funding and the overall administration. Ejide (2010) sees learning environment as a place where learners may work together and support each other as they use a variety of tools and information resources in their pursuit of learning goals and problem-solving activities. It is difficult to separate learning/school environment from curriculum issues. He is of the opinion that learning environment is the matrix that nurtures or inhibits learner growth. The school environment should be one that encourages positive social interaction, active engagement in learning and self motivation.

\section{Various Ways the Curriculum Can Be Made More Functional and Responsive for Human Capacity Development}

Some of the ways the school curriculum can be made functional and responsive for human capacity development as explained by Dike (2007), Obanya (2009), Offorma (2005), Alkali (2008) are:

Obioma (2010) contributed by saying that Technology is playing an important role in the life of the society. He explained that technology will lead to a more responsive labour market needs. Technical vocational Education Technology (TVET) has been linked to the rapid development of countries. The adoption of an appropriate TVET Programmes has led to acquisition of productive skills leading to the establishment of a constellation of competitive human capital in some developed economies such as India, Russia, Australia. He therefore advocates that such technology programmes be adopted in Nigerian school curriculum. 


\subsection{Conducting Needs Analysis}

Dike (2007) explains that need is what energizes individuals to action. It is the gap between our expectations (ideals/standards) and our status quo. Needs analysis is defined as the development and use of appropriate instruments to identify the prioritize organizational/national needs. He explains that the central place of needs analysis in curriculum improvement has historical antecedents. "The history date back to cold war era in which the then Soviet block and USA and her NATO allies had a cat and mouse relationship. In the mist of the tension, the Soviet Union launched sputnik in 1957. It came as a shock to American, and they had no immediate answer to the challenge of sputnik. US congress blamed her schools for not being able to use her schools in training men and women capable of responding to the challenges of sputnik". (Dike 2007:3) American therefore saw the need to restructure their school curriculum, paying much attention on science related courses (the hard skills). The Government equally decided to adequately fund the education sector.

Conducting needs analysis helps to know the areas in the education sector that needs to be refocused/refurbished and improved. Alkali (2008) in his own contribution on the importance of conducting needs analysis to enhance functionality in curriculum, has this to say, "We seem to accept that the primary purpose of education is to impart knowledge, produce enlightened citizens who can be useful to themselves and to the nation. Now, the new challenge is that our graduates must not only be enlightened but should be job creators. We should have no quarrel over this expectation in the areas of physical sciences, technology and some disciplines in the area of management and social sciences such as law, accountancy and business for example. But when we now come to discover that university graduate with $1^{\text {st }}$ class in Physics, Biology or mathematics are roaming about in our streets with no jobs after two years of graduation and finally ending up as air hostess. We have to think twice about the concept of job creation and job seeking. And again, when we spend billions of naira in the construction of roads, dams and houses. Our graduates of civil and water resources engineers roam about the streets holding their certificates for years without jobs or earning anything for living. I consider these anomalies in our development strategies as serious challenges which we must fight.

The first question to be asked, investigation to be made is whether our educational curriculum at all levels and more particularly at the university levels are shallow and need to be urgently reviewed in order to prepare our graduates for job creation". Obanya (2004) laments that our young graduates are unemployed not because the jobs are not available, but because their skills do not match the requirements for such jobs in the work place.

Need analysis is very necessary in striving to achieve functionality, it enables/helps to identify where/why we got it wrong initially and how to remedy and make amends.

\subsection{Adopting $21^{\text {st }}$ Century Curriculum Content}

Curriculum is road map for learning. It focuses on knowledge and skills that are judged important to learn. It is the only instrument through which our nation can be globalized. $21^{\text {st }}$ century curriculum as opines by Obanya (2009) is a curriculum that adopts the two complementary skill components which he called " $21^{\text {st }}$ Century-Compliant Education"

Table 1: Conventional Versus Contemporary Skills for 21st Century Curriculum

\begin{tabular}{|c|c|}
\hline CONVENTIONAL (HARD) SKILLS & CONTEMPORARY (SOFT) SKILLS \\
\hline Cognitive Intelligence & Emotional Intelligence \\
\hline Self-expression skills & Character formation skills \\
\hline (oral, written, etc) & (for strengthening the total person) \\
\hline Logical Reasoning Skills & Inter-personal skills \\
\hline (for analysis and problem solving) & $\begin{array}{l}\text { (for the individual to understand his/her personal } \\
\text { strength and weaknesses, as well as } \\
\text { possibilities/potentialities) }\end{array}$ \\
\hline $\begin{array}{l}\text { Computational Skills } \\
\text { (for mathematics reasoning) }\end{array}$ & $\begin{array}{l}\text { Inter-personal skills } \\
\text { (for understanding and 'teaming' with others) }\end{array}$ \\
\hline Design/manipulative skills & Life long learning skills \\
\hline (for purely technical reasoning and action) & (knowledge seeking skills) \\
\hline $\begin{array}{l}\text { Conceptual skills } \\
\text { (for generating ideas and translating them into 'action maps' }\end{array}$ & $\begin{array}{l}\text { Perseverance skills } \\
\text { ( for seeing ideas and projects through to fruition ) }\end{array}$ \\
\hline
\end{tabular}

\section{Source: Adapted from Obanya (2009; 22)}


Sternbery (2006) is of the opinion that the curriculum to be adopted in the $21^{\text {st }}$ century should be the curriculum that centres on developing students' competences. He calls it “the 3Rs Curriculum”:

Reasoning -This includes analytical, critical thinking, and problem solving skills.

Resilience - Which encompasses life skills such as flexibility, adaptability and self reliance.

Responsibility- Which is the application of intelligence, creativity and knowledge for a common good.

Ajala (2008) agrees that for development of human capacity, functional curriculum that prepares students for a changing and elusive job market and making of useful contributions to the greater economic and security needs of the nation in a competitive world is needed.

Offorma (2005) is of the opinion that for schools curriculum to be functional and responsive enough for human capacity development, the programs adopted by Covenant University called the Total Man Concept (TMC), Entrepreneurial Development Studies (EDS), and a Centre For Wealth Creation (CWC). Central to the strategy of producing a generation of well- rounded individuals (total man) that will go forth to impact their world be introduced to all the universities in the country.

\subsection{Adapting $21^{\text {st }}$ Century Teaching/Learning Styles/Strategies}

Today's knowledge Economy is making new demands on teachers in terms of their knowledge management functions. The knowledge economy demands the adoption of scientific teaching/ learning styles which Obanya and Fadoju (2008) explain to be:

- $\quad$ Broad based knowledge

- $\quad$ Life long learning skills

- $\quad$ Capacity for team work

- $\quad$ Capacity for practice oriented

- $\quad$ Participatory teaching

- $\quad$ Capacity to engage with society, focusing on development need areas and drawing from indigenous knowledge system as much as possible

- $\quad$ Interactive -Interconnected Team teaching

- $\quad$ Customized learning

- Interactive/Interconnected team work, a focus on systematic inquiry

- $\quad$ Self directed learning, exploring the world out there.

- $\quad$ Cooperative project work Report writing and port folio development.

- $\quad$ Problem - based Learning (PBL), an instructional strategy in which "students investigate rich and challenging issues and topics, often in the context of real world problems

- $\quad$ Cooperative learning which promote teamwork, leadership and other life/career skills while enhancing student academic performance.

\subsection{Adoption of Educational Technologies}

( $21^{\text {st }}$ century learning machines) These have transformed the world and changed the way we teach and learn. Sternberg (2006) explains that Educational Technologies enables students to employ simulations to "see" microscopic processes or "re-live" historic events.

- Communication Technologies facilitate giving and receiving feedback and allow students to progressively revise their work- all instructional strategies that have been shown to enhance learning.

- Digital tools of today make it possible to expand the walls of the classroom and enable integration of resources- scientific data, library collections, video and film archives from across the globe into the curriculum.

- Instructional data features real world contents facilitates the transfer of learning from school to life.

- Digital Communications make it possible to bring wisdom and lived experience of people in the community, as well as experts from the worlds of science, business, government and higher education, and thus, bring life to learning. 
Obioma (2 010) contributed by saying that Technology is playing an important role in the life of the society. He explained that Technology will lead to a more responsive labour market needs. Technical Vocational Education Technology (TVET) has been linked to the rapid development of countries. The adoption of an appropriate TVET programmes has led to the acquisition of productive skills leading to the establishment of a constellation of competitive human capital in some developed economies such as India, Russia, and Australia. He therefore advocates that such technology programme be adopted in Nigerian school curriculum.

\subsection{Involvement of Every Sector of the Society into Education Matters}

Since education is a matter that affects everyone, It is also imperative that it becomes the responsibility of everyone. "Education for All” implies "All for Education". Involving the people in education matters as explained by Obanya (2009, 2004) has its vertical and horizontal dimensions, beginning with one level of society (e.g. individuals, communities and going on vertically to local government areas, then to the state level through the geo-political zonal level to the national level. Involving the people here entails thinking along with, talking with, and working in concert with the people. He calls this "carrying the people along" or "being carried along by the aspirations of the people". He explained that it is one way of remedying the prevailing situation in which we have tended to have state and national education summits without education bases.

\section{What is Expected of Education/Knowledge to Pursue as We Journey into the Year 2020}

The year 2020 is currently everywhere in the air for achieving transformational changes in the life of many nations of the world.

Nigeria is not the only country with a vision 2020. It is considered a strategic turning point by the worlds' leading nations. The year 2020 as explained by Obanya (2009) is serious business all over the world. The thoughts on what the world would be like in 2020 is bedeviled with fears that remind us of 'decennial anxiety'.

Quoting Obanya on what is expected of education in the year 2020. "Countries at different levels of development stand to gain from engaging in the sign-posting rigour required by vision 2020. Doing so would require a heavy reliance on knowledge through education. This in turn means making knowledge as the 'essential commodity that a country should aim to appropriate and utilize'. Knowledge will also be the tool to use in acquiring knowledge as the essential commodity.

More important still, sustainable development is about people, for people by people. Enhanced human capacity is an essential requirement for human-centred development, and society needs developed human talents to make the construction of both physical and physical infrastructure possible, including design, construction, maintenance and even use.

Enhanced human capacity involves paying attention to the intellect as well as to values, attitude and comportment.

Enhanced human capacity is fully enhanced when a society has a critical mass of people whose intellect, values, attitudes and comportments have been qualitatively transformed. Such a society will also provide opportunities for continuing human capacity regeneration. The society will also have internalized the practice for harnessing knowledge as a tool for sustainable human development.

The point being made is development in true, and as envisioned by year 2020, has necessarily got to pass through the instrumentality of Education.

This is what is chosen to call "GEFA- Genuine Education For All”. (Obanya 2009:139)

The major qualification for entry into the world of the year 2020 as explained by Obanya (2009) is not just valuing knowledge. He said that valuing knowledge is not the same thing as valuing certificates. Rather, it means;

* creating opportunities for life long learning,

* promoting life long learning in school and out-of -school education,

* emphasizing how well (the extent to which one has learnt to learn) dimension of learning, in preference to how much (the sheer amount of facts and figures memorized ),

* encouraging and rewarding innovation and creativity in all aspects of normal life,

* shift social respect from the big man/woman to the great man/woman -valuing stature above status,

* systematically building knowledge into all aspects of decision making. 
Education Service Delivery Framework of GEFA addresses the question of 'what education for what all?' Which is a lot more than basic education. It is a lot more than sending children and adolescents to schools. Its main focus is 'responding to basic learning needs. Thus, every citizen (irrespective of life circumstances) has basic learning needs that should be met for society to advance.

The knowledge economy imperatives of year 2020 demand that these be met. A nation's ability to meet them will, to a very large extent determine the 'world' to which a nation will fit into in the sign post year 2020.

\section{Challenges Hindering Quick Actualization of Functional Curriculum for Human Capacity Development}

It is very appropriate that human development is one of late president Yar'Adua's Seven Point Agenda for the positive transformation of the economy and society, but unfortunately, there are numerous challenges faced in an attempt to make the curriculum functional for human capacity development. Some of such challenges include:

1) Lack of political will. Our leaders in authority always have nonchalant attitudes towards educational matters.

2) Lack of financial commitment on the part of the government (poor funding of the educational sector) The truth of the matter is that quality/functional education policies and programes are predicted on good politics. Good politics as explained by Obanya (2009) governs its funding. Our leaders are in the habit of merely throwing money at ill-articulated development ideas, channeling funds to non-priorities/low impact projects. Invariably, functionality in education is not $100 \%$ achievable without proper funding. What is said here is that reforms that will lead to functionality in terms of curriculum content, methodology, quality teacher production, instructional materials etc requires proper/adequate funding.

3) Lack of proper Curriculum assessment and proper monitoring of what goes in education sector. Obanya (2009) comments and said that it is very necessary to assess the curriculum content, but the emphasis in such assessment is not just whether the children are learning but mainly on what, how and why they are learning ( or not learning ). Thus the personal, home, background, school and environmental determinants of quality learning are analyzed to determine the form of needed corrective interventions. Obanya advised that we must not fail to educate for successful learning to avoid mass failure.

4) School environment decay. This could be traced to:

- Over crowed classrooms. There is a greater enrolment and increase in the students/pupils population without adequate classrooms to accommodate them,

- Dearth of facilities/deplorable classrooms. There is serious shortage of physical and psychological infrastructure in all most all the public primary and secondary schools in the country. Most of the books in our public school libraries have become so obsolete so as to appeal to the learners' interest. If nothing is done urgently as regards the deplorable condition of our school environment in the country, the hope and full expectations of achieving human capacity development in 2020 becomes only but a mere dream.

5) Collapse of reading culture among our students leading to high rate of exam malpractice. So many students these days no longer make reading as part of a habit, rather they depend on exam malpractice. Most of them cannot pass exams without one form of cheating or the other. Exam malpractice has become the order of the day in our schools especially at the secondary and tertiary levels, and this has indeed reduced the quality and worth of certificates issued to such students. With such questionable certificates, how can human capacity be developed to equip for vision 2020 ?

\section{Conclusion}

Any educational curriculum that aims at developing the human potentials must aim at functionality. That is to say, human being has to be educated (developed) to maximize his capacity to function as the motor of sustainable development, his education should also be sustainable (functional). Functionality in education is the vehicle that will drive us to the realization of vision 2020 dream. 


\section{Recommendations}

Agreeing with Nwankwo's statement: “The overall vision of the government of late president Yar'Adua is captured in the vision 2020, which aim at making Nigeria, one of the top twenty economics in the world by the year 2020. Given the economic revolution that is going on in the world economy, powered mainly by rapid developments in Information and Communications Technology (ICT), it is obvious that any country that wants to be reckoned with the global arena must be outstandingly advanced in Education, Nigeria has to redouble its efforts to massively educate various segments of the society in order to occupy a consequential position in the global economic scale" (Nwankwo 2008:2)

$21^{\text {st }}$ century skills for human capacity building need to be developed through pragmatic approaches. Having said this, these following recommendations have been made:

1. Government and other stake holders should demonstrate adequate political will power by providing the necessary school facilities for making the well designed school curriculum actually functional for the total preparation of individuals to cope with the modern world of today and actualize vision 2020.

2. At the tertiary level, as suggested by Odile (2009), Universities should adopt an open reform policy that will encourage for;

- co-operation with business skills such as entrepreneurship and leadership into their programmes, instill a more entrepreneurial spirit in university students and offer expertise in managing resources,

- introducing and launching university business forum where from time to time, business personnel/directors can be invited to have discussion and prefer expertise ideas, the sensitized, inspired students tap from their wealth of knowledge.

3. Nigeria can also borrow a leaf and adopt the experiences of countries life India, Malaysia and korea. These countries as explained by Alkali (2008) have established multipurpose institutions such as Technology Village where the well trained skilled engineers and other professionals meet with the semi skilled apprentices to impact high quality knowledge and training at minimal cost. This can be done by setting up a commission for a capacity building to develop programmes to promote and enhance creativity, talent and potential for global competitiveness.

4. Also at the tertiary level, Obanya (2010) recommended that as still part of reform, Nigeria can equally borrow a leaf from korea where they have come up with a more elaborate programmes that focuses more on internalization of research and teaching teams. The programme will promote 'new growth technologies' and promote interdisciplinary studies that consolidate the fields of basic sciences and humanities and social sciences which will contribute to national, social and academic development.

5. At the basic level, since UBE is meant to move Nigeria towards the goals of Education for All, Obanya (2010) is of the opinion that some sort of re-positioning is required or else it is unlikely to achieve both EFA and MDGs.

Re-positioning the UBE is all about a re-kindled meaningful Access Strategy which is the one that:

- Speaks the message of meaningful access among stake holders.

- Makes meaningful access the goal of EFA related programmes

- Incorporates action research - monitoring and evaluation procedures that dwells on progress towards the attainment of meaningful access.

\section{References}

Ajala, J.A. (2008). Primary-sec. education curriculum in Nigeria: yesterday, today and tomorrow. In B. Marcia, A. Rashid (Eds) Education for millennium development. (Essays in honour of Prof. Michael Omolewa). Ibadan: Spectrum books Ltd. (2): pp. 171-188

Alkali, M.N. (2008). Challenges and opportunities for the development of human capital in the content of global competitiveness. (Paper presented at the National Education Research and Development Council (NERDC) Conference Centre), Abuja: $19^{\text {th }} 20^{\text {th }}$ Nov. pp. $2-5$.

Dike, H.I. (2009). Refocusing education for relevance and sustainable development in Nigeria. (A lead paper 
presented at the $9^{\text {th }}$ annual conference of the National Association for the Advancement of Knowledge (NAFAK) held at Rivers State College of Education. $15^{\text {th }}-18^{\text {th }}$ March.) pp.6-10.

Ejide, B. (2010). Innovations in the learning environment. (Paper presented at the annual conference of the National Council of Educational Psychology at College of Education Technical) Asaba: 20 $0^{\text {th }}$ June. Pp. 7-12.

Federal Republic of Nigeria. (2004). National Policy on Education. Lagos: NERDC publishers.

Nafisatu, D.M. (2008). Evolution of functional curriculum for poverty eradication, wealth creation, knowledge and innovation in the formal and non-formal systems: A case study of the nomad in Nigeria. (Lead paper Presentation at the National Conference on Education Reforms for Sustainable Development. Organized By NERDC) at the International Conference Centre Abuja. $19^{\text {th }}-20^{\text {th }}$ Nov. pp. 3-4.

Nwabuaze, B.O (2012). Crises and problems of education in Nigeria. Ibadan: Spectrum Book Ltd.

Nwankwo, M.N. (2008). Options for sustainable funding of education in Nigeria. (Paper presented at the National Conference on Educational Reforms for Sustainable development, organized by NERDC). at the International Conference Centre, Abuja: $19^{\text {th }}-20^{\text {th }}$ Nov. pp. 2-5.

Obanya, P. A.I., \& Fadoju, A.F. (2008). General pedagogy. Evans professional teacher - education services: Course 113. Ibadan: Evans Brothers Nigeria Publishers Ltd.

Obanya, P.A.I. (2004). Education for the Knowledge economy. Ibadan: Mosuro Publishers Ltd.

Obanya, P.A.I. (2009). Dream living and doing education. Ibadan: Educational Research and Study Group.

Obanya, P.A.I. (2009). Education for sustainable development. (Lead paper presented at the International Conference on Education for Sustainable Development). Ibadan: pp. 8-15.

Obioma, G. (2010). Driving the attainment of vision 20:2020 through human capacity development. (keynote address delivered at the $25^{\text {th }}$ annual congress of the Nigerian Academy of Education) at the Gloryland cultural centre, Yenagoa: 8-12 Nov. pp. 19-20.

Offorma, G.C. (2005). Curriculum for wealth creation. (A paper presented at the seminar of the World Council for Curriculum \& Instruction) held at the Federal College of Education. Kano: $10^{\text {th }}$ Oct. pp. 10-14.

Unachkwu, G.C. (2010). Improving learning environment and curriculum challenges of 2020. (Lead paper presentation delivered at the $25^{\text {th }}$ conference of Nigerian Academy of Education (NAE) at Gloryland cultural centre, Yenagoa: 8-12 Nov. pp. 3-5. 